\section{DE DE GRUYTER}

OPEN
Przedsiębiorczość i Zarządzanie Entrepreneurship and Management University od Social Sciences Publishing House

ISSN 1733-2486

Volume XVI, Issue 2, pp. 13-29

DOI 10.1515/eam-2015-0014

Małgorzata Jabłońska

University of Lodz

\title{
The Need to Support Regional Entrepreneurship. The Evidence from Poland's Eastern Border Regions and the Region of Łódź
}

\begin{abstract}
:
The purpose of this paper is to identify the factors which have the greatest impact on the development of regional entrepreneurship in the border regions of Eastern Poland and in the Łódź region. An attempt was made to characterize these regions in terms of attractiveness and power of attracting development factors mainly due to the fact that in each of these regions entrepreneurs meet the specific micro- and macro-economic determinants.
\end{abstract}

Key words: entrepreneurship, regional entrepreneurship, regional policy, regions, Eastern Poland.

\section{Introduction}

Entrepreneurial potential is regionally diversified. Regional entrepreneurship in the aspect of peripheral regions, such as the border regions of Eastern Poland and the central region - Łódź, is a subject of this paper (analysis for the provinces of Lublin, Podlaskie, Subcarpathian, and Łódź). The previous analyses indicate that in terms of entrepreneurial potential Polish eastern border regions rank last. The regions are characterized by unfavourable conditions for development of entrepreneurship, mainly due to poorly developed economic base. National Regional Development Strategy include border areas, particularly those that are located on the external borders of the EU, as the problem 
area, subject to strategic intervention in regional policy implemented by 2020 . The Łódź region is in opposition to the Polish eastern border regions and is characterized by a higher growth potential. Conclusions drawn from the Łódź region can serve as recommendations and allow the identification of differences in the determinants of regional entrepreneurship in the regions located in the area the state border and those who are better placed.

The purpose of this paper is to identify the factors which have the greatest impact on the development of regional entrepreneurship in the border regions of Eastern Poland and in the Łódź region. An attempt was made to characterize these regions in terms of attractiveness and power of attracting development factors mainly due to the fact that in each of these regions entrepreneurs meet the specific micro- and macro-economic determinants. Proper identification of the determinants of entrepreneurship in the regions covered by the analysis will make it possible to shape the policy to support the process of regional entrepreneurship. Implementation of this objective, however, requires first to develop a methodology for determining the level and dynamics of the development of regional entrepreneurship.

\section{Regional entrepreneurship}

Entrepreneurship of the region is treated as a synonym of the sector of enterprises operating in the region. This is a narrow approach to regional entrepreneurship [Kola-Bezka 2013, p. 52]. The concept of regional (macroeconomic) entrepreneurship is intrinsically related to the development of the region, which is accomplished by the establishment of new enterprises, their gradual development, creation of new resources, markets, technologies, products, and services, processes and transactions leading to the increase of their value [Lichnia 2011, p. 11]. The literature also suggests that regional entrepreneurship can be defined as the activities of the entities operating in the local area, which lead to the establishment of new enterprises in the area, resulting in economic development, thereby increasing the standard of living of its inhabitants and such activities of local authorities and business environment which stimulate the establishment of new enterprises and the development of technical and social infrastructure [Saar 2011, p. 12].

In broad terms, the regional entrepreneurship refers to the activities of the public and social sector [Kola-Bezka 2013, p. 35].

Enterprises classified as SMEs are the causative entities for regional entrepreneurship. Micro-, small- and medium-sized enterprises represent the overwhelming majority of enterprises operating in Poland (in the EU, 99.8\% of all enterprises are SMEs). In the light of the Central Statistical Office (CSO) 
data, SMEs operating in Poland generate nearly three-quarters of Polish GDP and every second zloty (47.3\%) in the structure of the share of GDP. In 2011, all enterprises invested 161.24 billion zlotys. The SMEs' investments amounted to 80.8 billion zlotys, or $50.1 \%$ of total investments. Micro-enterprises invested $17.5 \%$ (28.3 billion zlotys), small-enterprises $11.6 \%$ (18.8 billion zlotys). Investments of small- and medium-enterprises accounted for $21.0 \%$ (33.8 billion zlotys) [Raport.Polskie MSP na drodze ku nowoczesności, Lewia$\tan$ 2013]. The level of entrepreneurship in Poland is relatively high. According to the data presented by the Polish Agency for Enterprise Development (PARP), the rate of entrepreneurship, defined as the share of adults who have set up their own business or take steps to this end, is for Poland 25\%, while the EU average is $23 \%$. In addition, the Polish economy ranks sixth in the EU in terms of the number of enterprises. According to Eurostat data, there are 1.52 million enterprises in Poland and their number is gradually growing. In the past ten years, the number of new companies exceeded the number of those liquidated. In the year 2012 the number of newly registered enterprises amounted to approx. 518 thousand, an increase of almost $27 \%$ compared with the previous year. In turn, the number of liquidated companies in this year was about a quarter smaller than in 2011 and amounted to 311 thousand. In comparison with the EU average the SME sector in Poland is increasingly dominated by micro-enterprises and the share of small firms is about half that of the EU. The share of micro-enterprises in the total number of companies in Poland is $95.9 \%$ (in the EU - 92.5\%). The share of small firms in the SME population in Poland (3.1\%) is about half the size of the EU average $(6.2 \%)$, while the share of medium-sized enterprises is close to the EU average $(0.9 \%$ Poland, 1.0\% - EU). majority, i.e., 92.1\% of all entrepreneurs in SME sector are natural persons conducting business. Legal persons and entities without legal personality represent $7.9 \%$ of small- and medium-sized enterprises. The Polish SMEs operate primarily in services and trade [Raport o stanie sektora małych i średnich przedsiębiorstw w Polsce w latach 2011-2012, 2013, p. 42].

Each region has developed entrepreneurship in a different way. This is mainly due to the fact that there are no two regions, which would be characterized by the same set of factors determining the establishment of enterprises on its territory. The differences stem both from internal (endogenous) and external (exogenous) factors. 


\section{Figure 1. Exogenous and endogenous factors determining regional entre- preneurship}

Exogenous factors

\section{External}

Globalization of economy

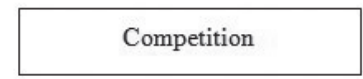

Foreign investments

The country's economic ties

Restructuring of the

economy

\begin{tabular}{|c|}
\hline Systemic solutions \\
$\qquad$ Legal regulations \\
\hline Internal \\
\hline
\end{tabular}

Socio-cultural factors

Entrepreneurial climate

Dynamics of economic growth of the region

Infrastructure

\begin{tabular}{|l|l|l|l|l|}
\hline $\begin{array}{l}\text { Advantages and resources of } \\
\text { the natural environment }\end{array}$ & Local labour market & \\
\end{tabular}

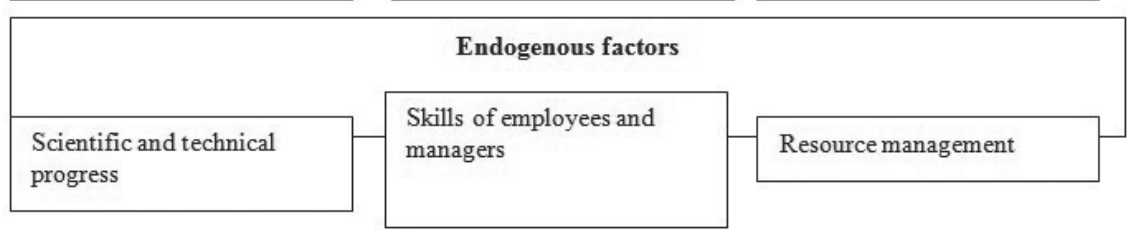

Source: author's own compilation. 
Exogenous factors are related to the environment in which the enterprise operates. Those which relate to external conditions to the region, are universal, because create equal conditions for operation of economic entities. In contrast, exogenous internal conditions occur with varying intensity in different regions [Kola-Bezka 2013, p. 55]. They reflect the opportunities and risks which are inherent to the implementation of national economic policy. These are macroeconomic factors. They can be divided into three main groups:

- Economic,

- Legal,

- Institutional.

Compilation of micro- and macro-economic factors is a contribution to the creation of conditions conducive to the generation of entrepreneurial behaviour in the region. These factors decide also about the investment attractiveness of regions. 


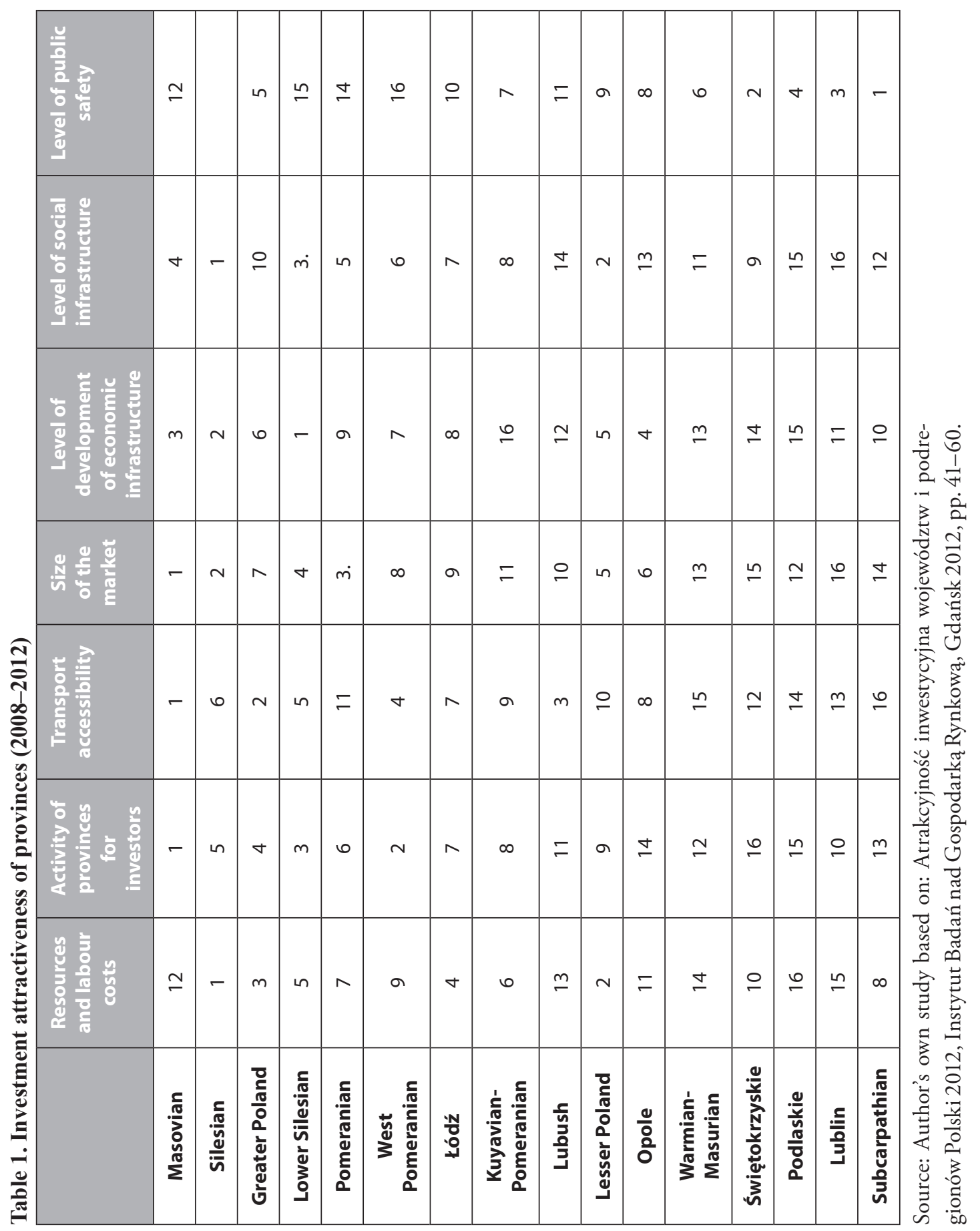


Research results presented above show the image of Polish regions in terms of investment attractiveness which is one of the most important determinants of local and regional entrepreneurship. Investment attractiveness is primarily understood as the ability to encourage investing by offering a combination of location advantages possible to achieve when doing business. The advantages result from the specific characteristics of the area in which business is conducted. These benefits are referred to as location factors [Atrakcyjność inwestycyjna województw i podregionów Polski 2012, p. 11]. Instytut Badań nad Gospodarką Rynkową [Gdansk Institute for Market Economics] has identified seven groups of factors which have the greatest impact on the creation of new businesses in the surveyed regions.

\section{Entrepreneurship in the eastern Polish border regions: Analysis}

Eastern provinces (regions) of Poland are classified as the least economically developed European regions. In connection with the implementation of the cohesion policy, which aims to reduce development disparities of regions, more attention has been paid to the eastern Polish regions, as well as the border regions, which are largely at risk of marginalization.

There are many definitions of a border region. However, in the literature, it is most often an area which is a part of a geographic space determined by its position along the state border, on its one side. It is a subsystem of a territorial socio-political system which is the State, but at the same time it is composed of subsystems, i.e., local territorial political and social systems. In relation to other administrative regions its specificity lies in the territorial environment which makes it more vulnerable to changes in international relations than inland regions [Miszczuk 2013, p. 60].

Polish Eastern regions are among the least economically developed regions of the European Union. Historical factors relating to the effects of World War II and the policy pursued by the communist government are responsible for this situation. As a result of this policy $40 \%$ of investments have been located in the Upper Silesian Industrial District. The unfavourable government policy was characterized by centralization of decision-making and resulted in the gradual deepening of the development disparities between the regions of Eastern Poland and the rest of the country. From the moment of Poland's accession to the European Union the economic development of these regions has been determined mainly by progressive economic transformation and European integration, and cohesion policy implemented under European integration, which aims to promote the harmonious development of the European Union by reducing disparities between the levels of development of regions. 
The advantages of Polish eastern border regions include: the level of education higher than in other regions and emerging clusters of modern industries, i.e., aviation, milk processing, cement, and automobile tires which are defined as regional growth centres. 
Table 2. Characteristics of the provinces of Lublin, Subcarpathian, and Podlaskie

\begin{tabular}{|c|c|}
\hline $\begin{array}{c}\text { Province } \\
\text { (voivodeship) }\end{array}$ & Description \\
\hline Lublin & $\begin{array}{l}\text { - The third largest region in Poland, it represents } 8 \% \text { of the area } \\
\text { of Poland, } \\
\text { - It is inhabited by } 2.2 \text { million people, } \\
\text { - Represents } 25 \% \text { of the area covered by the Operational } \\
\text { Programme Development of Eastern Poland } \\
\text { - Borders with Belarus and Ukraine, } \\
\text { - } 4 \text { cities with powiat (county) status, } \\
\text { - } 213 \text { municipalities, } \\
\text { - } 3645 \text { solectwos (villages), } \\
\text { - The least populated and urbanized region, } \\
\text { - Low level of accessibility, } \\
\text { - Slowing dynamics of development, } \\
\text { - Low share of market services and industry, } \\
\text { - High share of agriculture, } \\
\text { - Low labour productivity, } \\
\text { - Unfavourable structure of the economy, } \\
\text { - Low competitiveness, } \\
\text { - Poor innovation, } \\
\text { - The dominance of agriculture as a sector with low added } \\
\text { value, } \\
\text { - Predominance of low-tech industry, } \\
\text { - Low rate of modernization and replacement of fixed assets, } \\
\text { - Large surplus of labour supply over demand despite the } \\
\text { lower unemployment rate, } \\
\text { - High level of hidden unemployment, } \\
\text { - low standard of living of the inhabitants of the region, } \\
\text { - Fragmentation of agricultural holdings, } \\
\text { - A decrease in acreage due to the resting of land (fallow } \\
\text { culture) and afforestation, } \\
\text { - Tourism is an advantage of the region, } \\
\text { - Favourable position on the international transport route - } \\
\text { the pan-European East-West corridor, which allows access to } \\
\text { foreign markets, especially Ukraine and Belarus, } \\
\text { - Key industries include: renewable energy, biotechnology, } \\
\text { furniture industry, information technology, aviation, } \\
\text { construction, agriculture, tourism, processing and food } \\
\text { industry, science, chemistry, medical services. }\end{array}$ \\
\hline
\end{tabular}




\begin{tabular}{|c|c|}
\hline Subcarpathian & $\begin{array}{l}\text { - The region represents } 5.7 \% \text { of the country's area and } 18 \% \text { of } \\
\text { the Eastern Poland's area, } \\
\text { - Is } 15 \text { th in the country in terms of GDP per capita, } \\
\text { - Low wages (ranks 16th in the country), } \\
\text { - Low number of economic entities, } \\
\text { - Low number of business entities with foreign capital, } \\
\text { - Poor technical, social, and economic infrastructure, } \\
\text { - Poor investment attractiveness, } \\
\text { - Large role of industry, } \\
\text { - The industrial structure is dominated by aviation, } \\
\text { electromechanical, chemical, and food industry which together } \\
\text { produce } 70 \% \text { of industrial production of the province, } \\
\text { - In terms of employment medium- and large-sized enterprises } \\
\text { of the public sector prevail, } \\
\text { - Climatic and geographic conditions create unfavourable } \\
\text { conditions for agriculture, } \\
\text { - The share of rural population is } 60 \% \text { and is the largest in the } \\
\text { country, } \\
\text { - Villages are overpopulated } \\
\text { - Small farms dominate in the region, with an average size of } \\
3.5 \text { ha, } \\
\text { - Good conditions for the development of tourism, recreation, } \\
\text { and leisure, } \\
\text { - The occurrence of mineral waters is an asset, } \\
\text { - Key industries include metallurgy, furniture, information } \\
\text { technology, aviation, agriculture, tourism, food processing and } \\
\text { food industry, machinery, and chemicals. }\end{array}$ \\
\hline
\end{tabular}




\begin{tabular}{|c|c|}
\hline Podlaskie & $\begin{array}{l}\text { - The region represents } 6.5 \% \text { of the country's are and } 20.4 \% \text { of } \\
\text { the Eastern Poland's area, } \\
\text { - Podlaskie is a typical agricultural region, } \\
\text { - Over-staffing accompanied by frequent unemployment and } \\
\text { a low degree of marketability of production, } \\
\text { - An average area of agricultural acreage of one farm is } \\
\text { significantly larger than the national average, } \\
\text { - Podlaskie is characterized by one of the lowest levels of } \\
\text { economic development, } \\
\text { - Podlaskie has one of the lowest shares of industry in gross } \\
\text { value added, } \\
\text { - A large share of the SMEs sector is concentrated in the cities, } \\
\text { - Lack of interest by foreign investors, } \\
\text { - Low attractiveness of the region, } \\
\text { - Low level of GDP, } \\
\text { - Market capacity is small, } \\
\text { - Low degree of urbanization and infrastructure development, } \\
\text { - Underdeveloped industrial production, } \\
\text { - Not very competitive staff } \\
\text { - Low adaptability of the unemployed to the new conditions, } \\
\text { - Inadequate instruments and institutions of business } \\
\text { environment focused on learning, } \\
\text { - A region of high purity and naturalness of the natural } \\
\text { environment, } \\
\text { - Multicultural and multinational region, ethnically the most } \\
\text { diverse in the country, } \\
\text { - Attractive to tourists, } \\
\text { - Poor transport network, } \\
\text { - Lack of access to water supply and sewage system, } \\
\text { - Key industries include: furniture, tourism, food processing } \\
\text { and food industry, and machinery. }\end{array}$ \\
\hline
\end{tabular}

Source: Author's own study based on: Strategia rozwoju społeczno-gospodarczego Polski Wschodniej do roku 2020 [Strategy for Socio-economic Development of Eastern Poland until 2020], the Ministry of Regional Development, Warsaw 2008, pp. 17-19 and Raport. Rozwój struktur klastrowych w Polsce Wschodniej [The development of cluster structures in Eastern Poland], the Ministry of Regional Development, Warsaw 2007, pp. 131-132. 
Polish eastern border regions are the regions which do not create favourable conditions for the generation of pro-entrepreneurial behaviour. Due to the unfavourable employment structure (agriculture plays the dominant role here), these are poorly industrialized regions, underinvested, outdated with a rare network of cities, characterized by the poor condition of technical infrastructure and low efficiency of public administration. Consequently these provinces have poor innovation and poor competitiveness. The aviation industry is the only dominant innovation industry in the regions of Eastern Poland. The aviation enterprises in Eastern Poland represent 90\% of the whole Polish aviation industry.

\section{Entrepreneurship in the tódź region: Analysis}

Łódź Province is one of sixteen provinces in Poland. It is situated in the central part of the country and borders the following provinces: Greater Poland, Kuyavian-Pomeranian, Masovian, Opole, Silesian, and Świętokrzyskie. The size of the province is 18,219 square kilometres. Łódź Region consists of 21 powiats [counties] and 3 towns with powiat status. There are 177 municipalities in the region, including 133 rural municipalities, 18 municipalities and 26 urban-rural municipalities [Statistical Yearbook of the Regions 2012: Poland]. In 2010, more than 256 thousand enterprises registered in the REGON register were operating in the Łódź province which accounted for over $6 \%$ of all enterprises registered in Poland. In 2010, there were over 101 enterprises registered in the REGON register per 1,000 inhabitants in the region (Table 5.2).In this respect Łódź ranked ninth in Poland, as in 2009. In the ranking of start-ups per 1,000 inhabitants the province ranked eighth (sixth in 2009). At the same time in the ranking of liquidated companies the region has moved from the last position to the 12th, ahead of four regions. In respect of SMEs with foreign capital the region has maintained its tenth place [Raport o stanie małych i średnich przedsiębiorstw w Polsce 2011, p. 14].

Łódź Province is associated mainly with the rapidly developing textile industry, which experienced its glory days in the first half of the nineteenth century. The dominant role of this sector of industry accounted for the development of the region, its industrial specialization, and economic monoculture. Economic and political changes have triggered entrepreneurial attitudes among inhabitants which were reflected in the increase in the number of small and medium-sized enterprises since the early 1990s which were often established on the basis of the declining large textile enterprises [Sokołowicz 2008, p. 72]. In consequence of unfavourable development conditions of the region 
the dynamics of development has weakened resulting in the outflow of people to other major cities, mostly to nearby Warsaw. This is a negative phenomenon mainly because the region used to concentrate highly skilled workers and professionals educated at universities of Łódź. The advantages of the region include significant lignite resources owing to which the region has a surplus of cheap electricity, and very large reserves of thermal waters, which can be the basis for the development of renewable energy and spas in the region.

The potential of the region lies in its central position, both in the context of Poland and regions of Central and Eastern Europe. Foreign direct investments offer opportunities for the region to locate modern services and new industries. Large enterprises which decide to make investments in the Łódź region have a choice of two basic scenarios. They can either make investments in the technology park or in the Special Economic Zone (SEZ).

Technology Parks are a common solution conducive to the development of local entrepreneurship. These entities are characterized by the fact that in their area advanced technologies are produced and services are provided to related companies.' Internal organization of Technology Parks is a combination of business and residential areas. These are the tools of regional development [Mazur 2004, p. 29]. Today, four science and technology parks operate in the city of Łódź and in the region. They operate on the basis of mutual cooperation of local authorities with local initiatives in order to ensure preferential conditions for doing business. The objectives lying behind the idea of technology parks include attracting investors and creating new jobs.

From the perspective of harmonious economic development, special economic zones play a significant role in creating conditions for the development of industry. The main tasks of the SEZs include promotion of entrepreneurial behaviour and optimization of the use of factors of production for the successive reduction of unemployment in the region. The Łódź Special Economic Zone was set up in order to reduce the high rate of unemployment, create new competitive activities and modernize sectors of the local economy. The total area of the Zone is 1200 hectares and has been divided into 44 sub-zones. ${ }^{1}$ The actions of the Zone revolve around creating conditions for the functioning of new investors. Various initiatives taken by the authorities at the regional level are primarily aimed at achieving a high economic growth rate thus reducing development disparities. Without doubt the new enterprises contribute to this end.

${ }^{1}$ Polska Agencja Rozwoju Przedsiębiorczości [Polish Agency for Enterprise

Development]. 
Table 4. The number of newly registered enterprises

\begin{tabular}{|c|c|c|c|c|c|}
\hline \multirow{2}{*}{$\begin{array}{l}\text { Province } \\
\text { (voivodeship) }\end{array}$} & \multicolumn{5}{|c|}{ Year } \\
\hline & 2009 & 2010 & 2011 & 2012 & 2013 \\
\hline Łódź & 40,502 & 45,208 & 37,818 & 36,522 & 37,648 \\
\hline Masovian & 85,024 & 109,522 & 91,802 & 90,166 & 96,580 \\
\hline Lesser Poland & 55,340 & 63,312 & 52,490 & 51,212 & 51,634 \\
\hline Silesian & 70,510 & 81,362 & 63,686 & 61,516 & 62,164 \\
\hline Lublin & 27,166 & 31,260 & 26,404 & 25,634 & 26,972 \\
\hline Subcarpathian & 25,862 & 28,314 & 24,492 & 23,286 & 25,868 \\
\hline Podlaskie & 16,216 & 18,136 & 15,840 & 15,600 & 15,196 \\
\hline Świętokrzyskie & 16,766 & 19,250 & 16,146 & 15,654 & 16,994 \\
\hline Lubusz & 18,850 & 20,902 & 17,472 & 17,138 & 16,956 \\
\hline Greater Poland & 76,779 & 65,970 & 58,142 & 56,546 & 58,260 \\
\hline West Pomeranian & 35,566 & 36,804 & 33,586 & 31,114 & 33,070 \\
\hline Lower Silesian & 50,254 & 55,728 & 49,868 & 48,086 & 48,752 \\
\hline $\begin{array}{l}\text { K u y a v i a } n \text { - } \\
\text { Pomeranian }\end{array}$ & 33,162 & 34,896 & 32,818 & 29,730 & 32,764 \\
\hline Pomeranian & 44,636 & 48,890 & 43,530 & 41,530 & 44,412 \\
\hline $\begin{array}{l}\text { W a } \mathbf{r} \text { m i a } n- \\
\text { Masurian }\end{array}$ & 22,870 & 24,380 & 19,740 & 19,282 & 20,528 \\
\hline Opole & 13,836 & 15,222 & 12,190 & 11,218 & 12,776 \\
\hline
\end{tabular}

Source: Author's own calculations based on the data of Central Statistical Office (CSO).

According to the CSO data for the past five years, there are still development disparities between the Polish provinces. Most new companies register in the Masovian province. This is due to the fact that many see a chance for a market for their products and services in the capital, among others, because of the high population density. The data concerning the very city of Warsaw, however, distort the image of the whole province, and therefore the region has the highest rates of development and the lowest unemployment rates in the country. The lowest level of entrepreneurship is in the Opole province and the regions located on the eastern border. 
The development of entrepreneurship is determined by the dynamics of formation of new enterprises. The analysis shows that in the last year the Łódź region generated 37,648 new enterprises, but the dynamics of their establishing is much greater in the region of Lublin. The presence of a large city in the region which acts as a regional growth pole contributes to establishing new enterprises; Lublin is a good example here.

\section{Conclusions}

Research on regional entrepreneurship often argues that economic, legal, and institutional factors have a significant influence on the decision to start a new project. They are often cited as the main barriers to the development of the SME sector in Poland. This group of factors determining entrepreneurial behaviour in the regions depends on the policy of the regional government. This policy should therefore be carried out in such a way that these conditions would stimulate economic activity, rather than impair it. The issue of public aid is particularly important in the development of entrepreneurship.

The development of regional entrepreneurship is largely affected by the institutional environment of enterprises. Business environment institutions, their effectiveness and efficiency help businesses survive the most difficult moments in the first period after start-up. Business environment institutions include technological parks, entrepreneurship incubators (business incubators), transfer and technology centres, investor service offices in municipalities, loan institutions, private equity funds and venture capital funds. The academic entrepreneurship should be mentioned here. It determines the creation of links between the sphere of science and the sphere of economic practice.

This paper focuses on the determinants of development of entrepreneurship in the border regions of Eastern Poland, specifically in relation to the provinces of Lublin, Podlaskie, and Subcarpathian. These regions are characterized by specific conditions, mainly due to the specific border conditions in which they operate. The relatively low level of economic development of neighbouring countries hampers the development of entrepreneurship in these areas. As well as their location on the external border of the European Union. A study conducted by an international team of experts ${ }^{2}$ indicated that the inhabitants of the eastern Polish regions estimate that accession to the EU had a significant impact on the development of entrepreneurship in the region.

2 Research carried out in 2011. By an international team working at the Department of European Integration and Regional Studies at the Nicolaus Copernicus University in Torun, under the guidance of prof. W. Kosiedowskiego. 
Studies have shown that the Belarusian respondents at $54 \%$ until they see the benefits of such accession [Kola-Bezka 2013, p. 126].

Lublin province ranks low in comparison with other regions in terms of basic indicators of the level of entrepreneurship. A little over 26 thousand new enterprises in the private sector were established in the province in 2013. The development of entrepreneurship is characterized by a low growth rate. Due to the unused resources in the labour market and the lack of opportunities for earnings the region is characterized by a low standard of living. Using the positive aspects of the region, resulting in an increase in regional competitiveness, job creation and the development of inter-regional cooperation through the implementation of development policy should lead to sustainable development. Border regions of Subcarpathian province are characterized by good conditions for the development of tourism, recreation, and leisure. These factors are also barriers to the development of agriculture which is not very effective in these areas. Compared with other regions, Subcarpathian province has very poor key indicators determining the level of entrepreneurship. Regions of the province of Podlaskie are characterised by a very low level of economic development. The city of Białystok, which generates new enterprises, especially macro-enterprises, is the great advantage of the region. The Łódź province deserves special attention on account of the analysis of regional entrepreneurship. The region is centrally located, with great development potential and is characterized by high dynamics in terms of new enterprises and strong investment incentives which determine its location attractiveness.

\section{References}

Central Statistical Office (2012), Statistical Yearbook of the Regions - Poland 2012, Warsaw,

Instytut Badań nad Gospodarką Rynkową [Gdansk Institute for Market Economics] (2012), Atrakcyjność inwestycyjna województw i podregionów Polski [Investment attractiveness of Polish regions and sub-regions], Gdańsk.

Kola-Bezka M. (2013), Elementy teorii przedsiębiorczości i innowacyjności [Elements of the theory of entrepreneurship and innovation] [in:] W. Kosiedowski (ed.), Przedsiębiorczość i innowacyjność w procesie rozwoju regionów Europy Środkowo-Wschodniej [Entrepreneurship and innovation in the development of the regions of Central and Eastern Europe], Wydawnictwo Naukowe UMK, Toruń.

Lichniak I. (2011), Determinanty rozwoju przedsiębiorczości w Polsce [Determinants of the development of entrepreneurship in Poland], Oficyna Wydawnicza SGH, Warsaw. 
Mazur K. (2004), Specjalne strefy ekonomiczne jako nowe obszary przemystowe [Special Economic Zones as a new industrial areas], Wydawnictwo Politechniki Śląskiej, Gliwice.

Ministry of Regional Development (2007), Raport. Rozwój struktur klastrowych $w$ Polsce Wschodniej [The development of cluster structures in Eastern Poland], Warsaw.

Miszczuk A. (2013), Uwarunkowania peryferyjności regionu przygranicznego [Determinants of peripherality of the border region], Norbertinum, Lublin.

Polska Agencja Rozwoju Przedsiębiorczości [Polish Agency for Enterprise Development] (2011), Raport o stanie matych i średnich przedsiębiorstw $w$ Polsce [Report on the state of small and medium-sized enterprises in Poland (2011)], Warsaw.

Polska Agencja Rozwoju Przedsiębiorczości [Polish Agency for Enterprise Development] (2013), Raport o stanie sektora matych $i$ średnich przedsiębiorstw $w$ Polsce $w$ latach 2011-2012 [Report on the state of small and medium-sized enterprises in Poland in the years 2011-2012], Warsaw.

Raport. Polskie MSP na drodze ku nowoczesności [Report. Polish SMEs on the road to modernity], Lewiatan 2013.

Saar MA (2011), Jak samorządy lokalne moga wspierać rozwój przedsiębiorczości [How local governments can support the development of entrepreneurship], CeDeWu, Warsaw.

Sokołowicz M., E. (2008) Region wobec procesów globalizacji - terytorializacja przedsiębiorstw międzynarodowych (na przyktadzie regionu tódzkiego) [A region and the globalization processes: Territorialisation of multinational companies (Evidence from the region of Łódź)], Wydawnictwo Uniwersytetu Łódzkiego, Łódź. 